\title{
Molecular Diagnosis of Human Adenovirus in Children with Upper Respiratory Tract Infections
}

\author{
Rasha J. Khalaf ${ }^{1}$, Hula Y. Fadhil ${ }^{1 *}$, Iman M. Aufi ${ }^{2}$, Salah Ali Namdar ${ }^{2}$ \\ ${ }^{I}$ Department of Biology, College of Science, University of Baghdad, Baghdad, Iraq \\ ${ }^{2}$ Departmentof Virology, the National Central Public Health Laboratory (NPL), Ministry of Health, Baghdad- \\ Al-Andalus Street, Iraq
}

\begin{abstract}
Upper respiratory tract infections (URTIs) that are caused by human adenoviruses (HAdVs) affect in the whole population, but are more frequent in young children under the age of five years old. Due to the potential role of HAdVs in the URTIs cases of young children and there is no previous molecular study on these viruses in Iraq, this study aimed to detect of the prevalence of HAdVs in children suffering from URTIs by polymerase chain reaction (PCR). The DNA extracted from 203 nasopharyngeal and throat swabs, they were collected from children aged less than 15 years with the respiratory illness. In addition to 30 swabs obtained from healthy children as a control group. All samples diagnosed with PCR technique by using specific primer for the seven hyper variable regions (HVR-7) in the hexon gene. The results showed that 57 (28.08\%) were positive and 146 (71.9\%) were negative for HAdVs. The statistical analysis revealed a significant difference between groups $\left(X^{2}=11.064 ; P<0.01\right)$, where the viral DNA was detected in approximately a third (28.08\%) of the total study groups. Again results of our study showed that most patients with HAdV infection were younger than 5 years (85.5\%). Moreover, the results showed no significant difference in prevalence of HAdVs infections between males $29.82 \%$ (34/114) and females 25.84\% (23/89). In conclusion, using multiplex PCR for identify of multiple viral infections in the same time with highly sensitively.
\end{abstract}

Keywords: Human adenoviruses, Upper Respiratory Tract Infections, Hexon protein, Seven hyper variable regions.

\section{Introduction}

Human adenoviruses (HAdVs) (genus Mastadenovirus, family Adenoviridae) are among the most common respiratory viruses affect millions of people worldwide each year. Human adenoviruses (HAdVs) are well known pathogens that cause a variety of human illnesses includes upper respiratory tract illness, pneumonia, conjunctivitis, cystitis and gastroenteritis [1]. Upper respiratory tract infections (URTIs) that are caused by HAdVs affect in the whole population, but are more frequent in young children under the age of five years old. Also, in upper respiratory tract illness, HAdV accounts for up to $15 \%$ of known causative agents [2, 3]. Human adenoviruses (HAdVs) are non-enveloped, linear double-stranded DNA viruses. The icosahedral virions with a size of $60-90 \mathrm{~nm}$ in diameter, have 252 capsomeres (protein subunits) are 240 hexons and 12 pentons. Together proteins are involved in host-cell recognition and in the initial steps of cell infection [4]. Hexon quantitatively represents the dominant capsid protein and contains several regions that are conserved among different human serotypes [5]. Each hexon molecule contains 2 pedestal regions and 4 loops. Each pedestal region has 4 conserved regions, from $\mathrm{C} 1$ to $\mathrm{C} 4$, and 3 variable regions (V1, V2, V3). Loop 1 and loop 2 are encoded via the hyper variable regions of the hexon gene and are responsible for the serotype-specific epitopes. The hexon protein with serotype specific encoded via seven hyper variable regions (HVR-7) is the essential components for serotype identification of adenoviruses [6, 7]. Hence, the molecular methods demonstrate greater sensitivity than conventional assays for detection and identification of adenovirus in respiratory samples by using specific primer for amplifying the HVR-7 of hexon gene which provides easy, quick and accurate detection to all HAdVs serotypes $[8,9]$. Due to the potential role of HAdVs in the URTIs cases of young children and there is no previous molecular study on these viruses in Iraq, this study aimed to detect of the prevalence of HAdVs in children suffering from URTIs by polymerase chain reaction (PCR).

\section{Materials and Methods}

A total of 203 nasopharyngeal and throat swabs were tested in molecular technique to diagnose Human Adenovirus (HAdVs). They were collected from children aged less than 15 years (17 days - 14 year), from public hospitals at different Iraqi provinces in the period from August 2015 to April 2016. Symptoms of the respiratory illness associated with $\mathrm{HAdV}$ range from mild symptoms that include (fever over $38^{\circ} \mathrm{C}$, cough, sore throat, wheeze, cyanosis and shortness of breath) to more severe respiratory disease including laryngitis, croup, bronchiolitis, or pneumonia. In addition to 30 swabs obtained from healthy children as a control group. 


\subsection{DNA extraction}

All nasopharyngeal and throat swabs that give negatively result in influenza test were selected for DNA extraction using two types kit: Geneius Micro gDNA Extraction kit Geneaid Biotech (USA), and ZR Viral DNA kit (Viral DNA Extraction) Epigenetics company (USA) as described by the manufacturer's instructions [10].

\subsection{Polymerase Chain Reaction}

One pair of specific primer was tested to amplify adenoviral capsid genes. This primer was specific for the seven hyper variable regions (HVR-7) in the hexon gene of the Adenovirus, as a forward primer (AD1) (5'CTGATGTACTACAACAGCACTGGCAACATGGG -'3), and reverse primer (AD2) (5'GCGTTGCGGTGGTTAAATGGGTTTAC -'3) with a product size of 610 base pairs [11, 12]. Maxime PCR PreMix Kit (i-Taq) is a premixed ready-to-use solution for amplification of DNA templates by conventional PCR. This kit was provided by Intron Biotechnology, Korea. A master mix tube contains all the components required for conventional -PCR except template DNA. After optimization, the amplification program used $95^{\circ} \mathrm{C}$ for $2 \mathrm{~min}$ as initial denaturation, then followed by 30 cycle as $95^{\circ} \mathrm{C}$ for $30 \mathrm{sec}, 54^{\circ} \mathrm{C}$ for $45 \mathrm{sec}$ and $72^{\circ} \mathrm{C}$ for 45 sec; final extension done at $72{ }^{\circ} \mathrm{C}$ for $5 \mathrm{~min}$.

\subsection{Gel electrophoresis}

Amplified PCR products were electrophoresed through 1\% agarose gel in TBE buffer. Target bands of primer were visualized by staining with Red Safe Nucleic Acid Staining Solution. Positive and negative controls were included in each run. The results were counted as valid when there is no false-positive result was observed in the negative control reactions and when the positive control sample was positive [13].

\subsection{Statistical analysis}

The Statistical Analysis System-SAS (2012) program was used to effect of difference factors in study parameters. All values were calculated according to the positive results as percentages (\%). Differences between study groups and assays were analyzed by cross-tab and pearson chi-square $\left(\mathrm{X}^{2}\right)$ test. A value of $\mathrm{P}<0.05$ was considered statistically significant.

\section{Results And Discussion}

A total of 203 nasopharyngeal and throat swabs were selected as a study group from different Iraqi provinces for the detection of HAdV DNA. Results showed that 57 (28.08\%) were positive and 146 (71.9\%) were negative for HAdVs as tested by a conventional PCR and specific primers for amplifying the highly conserved sequences of the seven hyper variable region (HVR-7) of hexon gene (Figure 1). Polymerase Chain Reaction (PCR) can detect of the low viral load of suspect clinical samples and proved to be as rapid and sensitive assay for HAdVs detection in this study. These methods will be of direct use during outbreaks of a specific type when decision making is depended on these results. This method has been used by others for the detection the hexon gene region of Adenovirus genome [7, 14, 15]. Similar findings have been reported by Helen Sarantis et al., who tested hexon gene (HVR-7) that was able to detect all serotypes of human adenoviruses known at that time with high sensitivity [17].

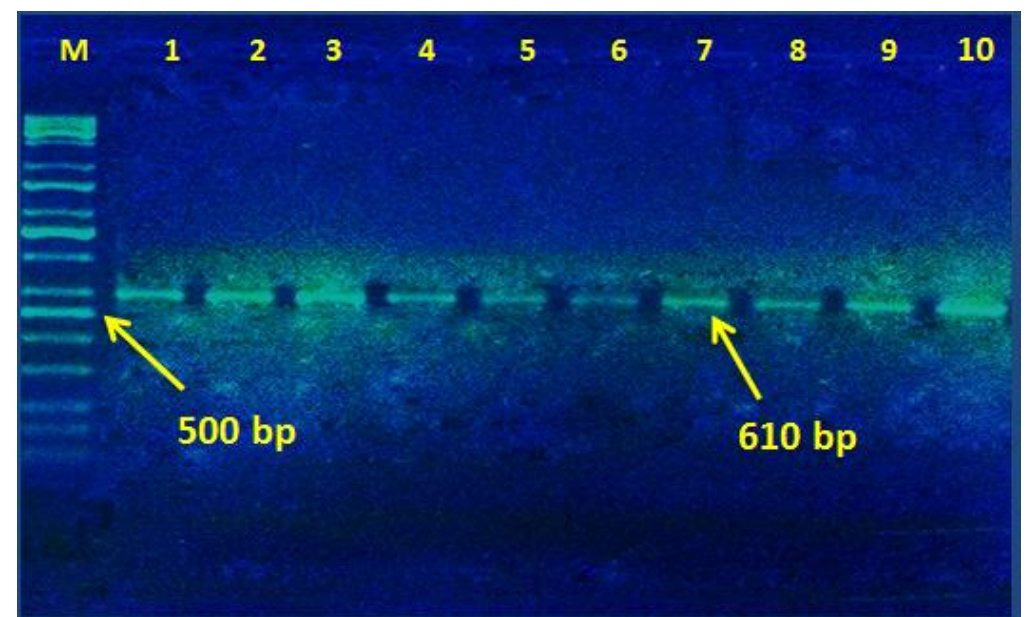

Figure 1. Amplification of adenovirus DNA targeting the 7-Hyper Variable Region (HVR-7). Amplicons (lanes 1- 10 represent high and low viral DNA copies $610 \mathrm{bp}$ ). Products run on a $1 \%$ agarose gel with red safe stain during gel electrophoresis. M: DNA Marker (ladder) 10.000-100 bp. 
The statistical analysis revealed a significant difference between groups $\left(\mathrm{X}^{2}=11.064 ; \mathrm{P}<0.01\right)$, where the viral DNA was detected in approximately a third (28.08\%) of the total study groups (Table 3-1). The frequency of HAdVs positive cases in our study was higher for most studies than that reported in the Middle East such as Turkey 26.2\% [17], Iran 14.4-22\% [18-20], Israel 18.3\% [21], Saudi Arabia 17.4\% [22]. Other parts of the world reported different values like Kenya 14\% [23], Korea 10.3\% [24], Australia 7.3\% [25], and Peru $6.2 \%$ [26]. In contrast, a high incidence of HAdVs was recorded of $83.5 \%$ in Taiwanese children with respiratory tract infections [27].

Table 1. Prevalence of HAdV in children with URTIs

\begin{tabular}{|c||c||c||}
\hline \multicolumn{1}{|c|}{ The results } & No. of cases & Percentage (\%) \\
\hline \hline Positive & 57 & 28.08 \\
\hline \hline Negative & 146 & 71.92 \\
\hline \hline Total & 203 & $100 \%$ \\
\hline \hline Chi-square & --- & $11.064 * *$ \\
\hline
\end{tabular}

$(* *)$ Indicate the high significant differences between study groups.

Meanwhile, the negative cases of suspected respiratory tract infection for HAdVs may explain other causes of RTI that may be due to viral infection other than Adenovirus. These could be several viruses are known to cause respiratory infections in humans [28]. Major pathogens that induce URIs are human rhinoviruses (HRVs), belong to Picornaviridae [29]. Other common causative agents are a respiratory syncytial virus (RSV), parainfluenza virus, enterovirus (EV) from the family Picornaviridae and genus Enterovirus, coronavirus, and influenza virus type A and B [30]. In addition, a number of novel human respiratory viruses, including human metapneumovirus (hMPV), coronavirus (CoV), polyomaviruses and human bocavirus (HBoV) are also contributing to respiratory infections [31]. While the major bacterial agents responsible for RTIs have remained the same for the past 20-30 years which include: Streptococcus pneumoniae, Haemophilus influenzae, Moraxella catarrhalis, Staphylococcus aureus, beta-haemolytic Group A Streptococcus and Pseudomonas [3].

According to the age of HAdVs infected children, the cases were classified into five groups (Figure 2). The mean age was $3.51 \pm 2.96$ years (month-12 years) and approximately $50 \%$ of them were from $\geq 3$ year old children. This represented the highest significant difference with other age groups $\left(\mathrm{X}^{2}=10.436, \mathrm{P}<0.01\right)$. Again results of our study showed that most patients with HAdV infection were younger than 5 years $(85.5 \%)$, which is a similar value were obtained in previous studies [32-34]. The result of the present study indicates that HAdVs infections acquisition are significantly depended on children age, while $36 \%$ were found in children aged $\leq 6$ years. A similar study in which high HAdV infections $(47.6 \%)$ were shown at the age group $\leq 1$ to $\geq 3$ years compared to age group $3-\leq 6$ years and $6-\leq 15$ years at $28.1 \%, 11 \%$, respectively [35]. The study finding is also, comparable to other studies of HAdV infection in other part of the world indicating that children under the age of 3 years were most susceptible to HAdV infection [36-38]. In previous experiments for the detection of HAdV in RTI, we observed that Children at age between 6 to 15 years usually have a lower rate of infection. It is more likely those children are infected early in life and therefore had acquired immunity to this infection [39].

The higher frequency of HAdVs that cause URTI in young children could be due to one or multiple factors such as: immune system immaturity of young children; physiological population and cultural characteristics; rapid inflammatory responses; functional immaturity of the Eustachian tube and close contact with other children either directly, for example at school, or indirectly through relatives or common places [3].

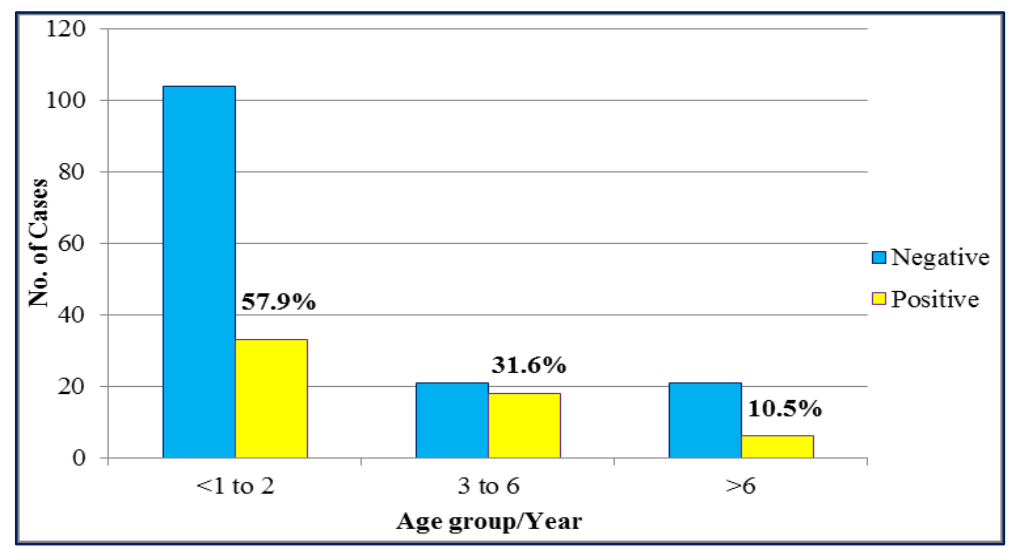

Figure 2. Distribution of positive and negative of HAdVs cases according to age groups. 
According to the gender susceptibility to HAdVs infections, this study showed no significant difference in prevalence of HAdVs infections between males 29.82\% (34/114) and females $25.84 \%$ (23/89) (Table 3-5) $\left(\mathrm{X}^{2}=1.37, \mathrm{P}>0.01\right)$. Other studies in different parts of the world also showed no significant differences in the prevalence of HAdV infections between males and females [31, 40, 41].

Table 2. Distribution of study samples according to gender in HAdV cases.

\begin{tabular}{|c|c|c|c|c|}
\hline Gender & No. of cases & Positive cases & Negative cases & Percentage of $+\mathrm{ve}$ \\
\hline Male & 114 & 34 & 80 & 29.82 \\
\hline Female & 89 & 23 & 66 & 25.84 \\
\hline Total & 203 & 57 & 146 & 28.08 \\
\hline Chi-square & --- & --- & --- & $* 1.376$ \\
\hline
\end{tabular}

Only limited studies showed significant differences between male and female in which the infectious rate of HAVs in males were higher than females [26, 35]. Also, Moattari et al., a study in Iran showed that the infectious rate of HAV was high in females than in males [20].

\section{Conclusion}

In conclusion, using multiplex PCR for identify of multiple viral infections in the same time with highly sensitively.

\section{References}

[1]. A. Shauer, Gotsman, I., Keren, A., Zwas, D. R., Hellman, Y., Durst, R. and Admon, D. Acute viral myocarditis: current concepts in diagnosis and treatment. Isr. Med. Assoc. J., 15, 2013, 180-185.

[2]. Q.Yan, Wujun, J., Zhengrong, C., Li, H., Yuqing, W., Feng, H., Wei, J., Xuelan, Z. and Xuejun, S. Epidemiology and clinical features of respiratory adenoviral infections in children. Eur. J. Pediatr, 173, 2014, 441-444.

[3]. E. Mansilla, Ciceran, A., Pignatari, S., Koatz, A. M. and Marengo, R. L. The place of immunomodulation in recurrent respiratory tract infections, an overlooked pandemic. EMJ Respir., 4(1), 2016, 3-9.

[4]. T. Lion. Adenovirus infections in immunocompetent and immunocompromised patients. Clin Microbiol Rev., 27, $2014,441-462$.

[5]. V. S. Reddy, Natchiar, S. K., Gritton, L., Mullen, T.M., Stewart, P. L. and Nemerow, G. R. Crystallization and preliminary X-ray diffraction analysis of human adenovirus. Virol., 402(1), 2010, 209-214.

[6]. A.Y. Mohd, Zarina, M. Z., Khairul Azuan, O., Nur Ismawati, A. R. and Zainah, S. Molecular characterization of adenovirus causing acute respiratory disease in Malaysia from 2003 to 2011. Academic Journals /JGMV., 5(1), 2013, 14-21.

[7]. F.M. Mbui, F. M., Achilla, R. A., Coldren, R. L. and Bulimo, W. D. Serotype Diversity of Respiratory HumanAdenoviruses amongst Pediatric Patients fromWestern Kenya, 2010-2012. Afr. J. Pharmacol. Ther., 5(3), 2016, 142-148.

[8]. M. Ephros, Friedman, B.C., Elhasid, R., Kra-Oz, Z., Shaked-Mishan, P., Sattinger, J. and Kassis, I. Incidence and clinical manifestations of adenoviral infection among children undergoing allogeneic stem cell transplantation. Isr. Med. Assoc. J., 11 (12), 2009, 744-748.

[9]. A. Watanabe, Carraro, E., Camargo, C., Diane Puerari, D., Sandra Guatura, S., Granato, C. and Bellei, N. Human adenovirus detection among immunocompetent and immunocompromised patients presenting acute respiratory infection. Rev Soc Bras Med Trop., 46(2), 2013, 161-165.

[10]. H. Y. Fadhil, Saleh, D.S. and Al-Hamdani, F.G. Detection of Human Papillomavirus-21 genotypes in a sample of Iraqi women with cervical abnormalities and cancer. Canadian J.pure and applied sciences, 8(1), 2014, 2671-2676.

[11]. L. Crawford-Miksza and Schnurr, D. P. Analysis of 15 adenovirus hexon proteins reveals the location and structure of seven hypervariable regions containing serotype-specific residues. J Virol., 70, 1996, 1836-1844.

[12]. H. Sarantis, Johnson, G., Brown, M., Petric, M. and Tellier, R. Comprehensive detection and serotyping of human adenoviruses by PCR and sequencing. J. Clin Microbiol,. 42(9), 2004, 3963-3969.

[13]. H.Y. Fadhil. Detection for respiratory syncytial virus RNA among children with flu-like illness using molecular assay. International Journal of Current Research, 6(11), 2014, 9455-9459.

[14]. U. Banik, Adhikary, A. K., Suzuki, E., Inada, T. and Okabe, N. Multiplex PCR assay for rapid identification of oculopathogenic adenoviruses by amplification of the fiber and hexon genes. J. Clin. Microbiol, 43, 2005, 1064-1068.

[15]. D. P. Rosete, Manjarrez, M. E. and Barrón, B. L. Adenoviruses C in non-hospitalized Mexican children older than five years of age with acute respiratory infection. Mem Inst Oswaldo Cruz, Rio de Janeiro, 103(2), 2008, 195-200.

[16]. C. Savon, Acosta, B., Valdes, O., Goyenechea, A., Gonzalez, G., Pinon, A., Mas, P., Rosario, D., Capo, V., Kouri, V., Martinez, P. A., Marchena, J. J., Gonzalez, G., Rodriguez, H. and Guzman, M. G. A myocarditis outbreak with fatal cases associated with adenovirus subgenera $\mathrm{C}$ among children from Havana City in 2005. J. Clin. Virol., 43, 2008, 152-157.

[17]. S. Bicer, Giray, T., Çöl, D., Çiler Erdağ, G., Vitrinel, A., Gürol, Y., Çelik, G., Kaspar, Ç. and Küçük, Ö. Virological and clinical characterizations of respiratory infections in hospitalized children. Ital. J. Pediatr. 39, $2013,22$.

[18]. S.S. Malekshahi, Azad, T. M., Yavarian, J., Shahmahmoodi, S., Naseri, M. and Rezaei, F. Molecular detection of respiratory viruses in clinical specimens from children with acute respiratory disease in Iran. Pediatr Infect Dis J., 29(10), 2010, 931-933.

[19]. M. Kahbazi, Fahmizad, A., Armin, S., Ghanaee, R. M., Fallah, F., Shiva, F., et al. Aetiology of upper respiratory tract infections in children in Arak city: a community based study. Acta Microbiol Immunol Hung, 58(4), 2011, 289-96.

[20]. A. Moattari, Emami, A., Pirbonyeh, N. and Yaghoobi, R. Detection of Adenovirus Infection Among Children with A cut Respiratory Disease during 2010-2012 in Shiraz, Iran. Arch pediatr. Infect Dis., 2(4), 2014, 5930.

[21]. M. Mandelboim, Dror, P., Azar, R., Bromberg, M. and Mendelson, E. Adenovirus Infection in Hospitalized Patients in Israel. Epidemiology and Molecular Characterization. J Clin Microbiol., 49, 2011, 597-601.

[22]. M. S. Al-Ayed, Asaad, A. M.., Qureshi, M. A. and Ameen, M. S. Viral etiology of respiratory infections in children in southwestern Saudi Arabia using multiplex reverse-transcriptase polymerase chain reaction. Saudi Med J., 35(11), 2014, 1348-1353 . 
[23]. Ahmed, J. A. ; Katz, M. A. ; Auko, E. ; Njenga, M. K. ; Weinberg, M. ; Kapella, B. K. ; et al. (2012). Epidemiology of respiratory viral infections in two long-term refugee camps in Kenya, 2007-2010. BMC Infect Dis. 12:7.

[24]. Z. Callaway, Kim, S. H., Kim, J. Y., Kim, D.W. and Kim, C. K. Adenovirus infection with serious pulmonary squeals in Korean children. Clin Respir J., 5(2), 2011, 92-8.

[25]. 25. T.P. Sloots, McErlean, P., Speicher, D.J., Arden, K. E., Nissen, M. D. and Mackay, I. M. Evidence of human coronavirus HKU1 and human bocavirus in Australian children. J Clin Virol,. 35(1), 2006, 99-102.

[26]. J.S. Ampuero, Ocaña, V., Gómez, J., Gamero, M. E., Garcia, J., Halsey, E. S. and Laguna-Torres, V. A. Adenovirus Respiratory Tract Infection in Peru. PLoS One, 7, 2012, e46898.

[27]. E.A. Ferone, Berezin, E.N., Durigon, G.S., Finelli, C., Felício, M. C., Storni, J.G., Durigon, E.L. and Oliveira, D. B. Clinical and Epidemiological aspects related to the detection of adenovirus or Respiratory syncytial virus in infants hospitalized for acute lower respiratory tract infection. J Pediatr (Rio J), 90(1), 2014, 42-9.

[28]. R. Eccles, Understanding the symptoms of the common cold and infl uenza. Lancet Infect Dis., 5, 2005, 718-725.

[29]. A.M. Fendrick, Viral Respiratory Infections Due to Rhinoviruses: Current Knowledge, New Developments. A.M. J .Th er., 10, 2003, 193-202.

[30]. M. Passioti, Maggina, P., Megremis, S. and Papadopoulos, N.G. The common cold: potential for future prevention or cure. Curr Allergy Asthma Rep., 14, 2014, 413.

[31]. S.L. Wang, Chi, C.Y., Kuo, P.H., Tsai, H.P., Wang, S.M., Liu, C.C., et al. High incidence of human adenoviral co-infections in taiwan. PLoS One., 8(9), 2013, ee75208.

[32]. Y.J. Kim, Hong, J.Y., Lee, H. J., Shin, S. H., Kim, Y.K., Inada, T., Hashido, M. and Piedra, P. A. Genome type analysis of adenovirus types 3 and 7 isolated during successive outbreaks of lower respiratory tract infections in children. J Clin. Micro biol., 41(10), 2003, 4594-4599.

[33]. S.B. Selvaraju, Kovac, M., Dickson, L. M., Kajon, A. E. and Selvarangan, R. Molecular in Kansas City children. J ClinVirol., 51(2), 2011, 126-131.

[34]. Y. Jin, Zhang RF, Xie ZP, Yan KL, Gao HC, Song JR, Yuan XH, Hou YD, Duan ZJ. Prevalence of adenovirus in children with acute respiratory tract infection in Lanzhou, China. Virol J., 10, 2013, 271.

[35]. P. Sriwanna, Chieochansin, T., Vuthitanachot, C., Vuthitanachot, V., Theamboonlers, A. and Poovorawan, Y. Molecular characterization of human adenovirus infection in Thailand, 2009-2012. Virol. J., 10, 2013, 193.

[36]. J. Abd-Jamil, Teoh, B.T., Hassan, E.H., Roslan, N. and Abubakar, S. Molecular identification of adenovirus causing respiratory tract infection in pediatric patients at the University of Malaya Medical Center. BMC Pediatr., 10, $2010,46$.

[37]. T.P. Tsou, Tan, B. F., Chang, H.Y., Chen, W.C., Huang, Y.P., Lai, C.Y., Chao, Y. N., Wei, S. H., Hung, M. N., Hsu, L.C., Lu, C.Y., Shao, P. L. , Mu, J.J., Chang, L.Y. and Liu, M.T. Unknown Pathogen Discovery/Investigation Group, Huang, L. M. Community Outbreak of Adenovirus, Taiwan, 2011. Emerg Infect Dis., 18, 2012, 1825-1832.

[38]. C.S. Khor, Sam, I. C., Hooi, P. S., Quek, K. F. and Chan, Y.F. Epidemiology and seasonality of respiratory viral infections in hospitalized children in Kuala Lumpur, Malaysia: a retrospective study of 27 years. BMC Pediatr., 12, $2012,32$.

[39]. R.J. Cooper, Hallett, R., Tullo, A. B. and Klapper, P. E. The epidemiology of adenovirus infections in Greater Manchester, UK 1982-96. Epidemiol and Infect., 125, 2000, 333-345.

[40]. S. Arabzadeh, Parizi, M., Molaie, H., Afshar, A. and Salari, A. Evaluate the prevalence of Para-influenza, Adenovirus \& respiratory Syncy 7 tial Virus with multiplex PCR in children referees to teaching hospitals with bronchiolitis symptoms. Kerman Univ Med Sci., 15(4), 2008, 305-11.

[41]. L. Zou, Zhou, J., Li, H.., Wu, J., Mo, Y., Chen, Q., et al. Human adenovirus infection in children with acute respiratory tract disease in Guangzhou, China. APMIS, 120(8), 2012, 683-688. 